\title{
International Framework Agreements for Workers' Rights? Insights from River Rich Cambodia
}

\author{
Catia Gregoratti, Lund University, Sweden \\ Doug Miller, Northumbria University, UK
}

\begin{abstract}
The international framework agreement concluded between the Spanish fashion retailer Inditex SA and the International Textile, Garment and Leather Workers Federation (ITGLWF) was lauded as the first IFA to apply to an outsourced apparel supply chain. Central to the implementation approach of both parties is an understanding that for progress to be made in the advancement of core labour standards in producing countries, compliance efforts need to be rooted in the promotion of freedom of association, dialogue and collective bargaining. This approach has informed the interventions of the ITGLWF and the multinational Inditex SA to resolve trade union recognition disputes in a number of developing countries. This article presents and critically examines an early test case of this approach at a knitwear factory in Cambodia. Drawing on empirical research, we find that the intervention resulted in the resolution of a recognition dispute, which led to significant membership gains for a local union and the removal of fixed duration contracts. However, the article raises questions about the effectiveness and sustainability of such an approach for advancing freedom of association and collective bargaining throughout a multinational apparel supply chain, particularly in the current global economic climate.
\end{abstract}

\section{KEYWORDS}

apparel supply chains, Cambodia, corporate social responsibility, International Framework Agreements, trade union rights

\section{Introduction}

Multiple forms of exploitation and denial of fundament rights at work continue to be widely documented and condemned by Global Union Federations (GUFs) and human rights NGOs, particularly in the context of outsourced garment, textile and apparel supply chains. The lack of such rights stem from relaxed labour laws and from processes of global restructuring which have accelerated the relocation of mass production and conferred global buyers - brands, retailers and export traders - the power of pitting against each other an increasingly large number of Asian, African and Latin American suppliers competing to attract steady orders. As explained by Barrientos (2008: 982), by relying on outsourced production, buyers are able 'to exert pressure on suppliers to reduce costs, reduce lead times and increase just-in-time efficiency.' Trickling down the supply chain is a downward pressure on labour 
conditions manifested in 'job insecurity, poverty wages, long hours, unhealthy working conditions, abusive management, child labour and the suppression of trade union rights' (Miller 2004: 219).

Against this background our paper analyses the implementation of the first International Framework Agreement (IFA) signed between a multinational in the sector - in this case the Spanish fashion retailer Inditex SA and the International Textile Garment and Leather Workers Federation (ITGLWF). A more detailed analysis of the evolution and content of this agreement, signed in 2007, has been carried out elsewhere (Miller, forthcoming). Here, we are concerned to use a case study approach to appraise the introduction of a series of collective agreements in an Inditex supplier as means to resolve a number of code violations. The choice of River Rich, one of Inditex's main Cambodian suppliers of knitwear, is not random, and is seen as constituting a test case for the industry (See: Oka 2010: 71). River Rich is in fact one of the first factories where the ITGLWF and Inditex have facilitated the negotiations of agreements which contain clauses for the management of labour relations and the respect of core labour conventions. In charting the labour disputes at the River Rich factory and their subsequent resolution, we unravel the tensions in employment relations in a country that has been rapidly enmeshed in the globalisation of garments production. We argue that transnational solidarity and the intervention of Inditex and the ITGLWF to install what has been termed 'a mature industrial relations approach' did indeed bring about some positive changes in employment relations and trade union recognition at the factory. However, the fickle nature of outsourced apparel production raises serious questions about the overall effectiveness and long-term sustainability of such an approach, which the economic crisis has served only to bring into much sharper focus.

\section{Corporate Social Responsibility and Trade Union Rights}

The working conditions of garment workers in the global South mirror those experienced in Western sweatshops almost a century ago and, perversely, in the remnants of production facilities still to be found in a number of buying countries today. The fundamental problem for organised labour is that those social gains which garment workers in the North managed to secure through unionisation, hard-fought collective action and collective bargaining, were lost at the point of relocation of production to the South, posing significant barriers for garment workers to organise and advance their rights. Lipschutz (2005: 76) summarises the hindrances to freedom of association in three key propositions: 'capital views unionisation as an obstacle to efficiency and profits; states worry that labour activism will drive capital away; and workers fear - with good reason - that attempts to organise will get them fired'. Even in countries where freedom of association and collective bargaining are permitted, restrictions to unionisation and strikes are often sanctioned in labour law, and employers' trade union busting techniques are not infrequent. The situation on the ground is further complicated by employer sponsored alternative forms of worker representation purporting to satisfy freedom of association code principles and intransigence to engagement in collective bargaining. For the workers, on the other hand, 'yellow unions' are often the only safe channels for representation in the workplace (ITUC 2007a). 
The regulatory gap, arguably resulting from the lack of an ILO enforcement mechanism and some countries engaging in a regulatory race to the bottom in an effort to remain competitive in a post-quota world, has been progressively supplanted by the emergence of soft regulatory mechanisms operating under the banner of 'corporate social responsibility' (CSR). Spurred by the emergence of the second 'anti-sweatshop' movement and consumer pressure, throughout the past two decades, reputation conscious multinational corporations (MNCs) have resorted to the adoption of codes of conduct and participation in nongovernmental systems of labour standards monitoring (Jenkins, Pearson and Seyfang 2002, O'Rourke 2003). Codes, whether at the level of the firm, within sector specific or crosssectoral initiatives, draw upon international standards and conventions that MNCs are expected to uphold throughout their supply chains. A number of assessments on the efficacy of codes as tools for the advancement of core labour standards in the global South have just begun to emerge. Echoing the concerns of number of earlier studies (Pruett 2005; Locke, Fei and Brause 2006), Wells (2007: 65) in a seminal review on the impact of codes and monitoring mechanisms argues that 'overall, and notwithstanding evidence of improved code compliance among some first-tier suppliers, especially in respect to child labour, forced labour and health and safety...there is considerable evidence that code compliance remains weak and monitoring largely ineffective.'

Significantly, within the emerging system of voluntary regulation, trade union rights continue to remain an area of political contention and limited impact. O'Brien (2002) explains that for some corporations, including one of the global retailers involved in the River Rich case, trade union rights are not corporate responsibilities but political matters, the jurisdiction of which rests solely within states. When freedom of association and the right to collective bargaining become enmeshed in private CSR interventions and codes of conduct, recent studies confirm that very little progress has been made by transnational buyers or local firms to guarantee or enable unionisation. In a survey of six high-profile initiatives addressing freedom of association and collective bargaining in transnational supply chains, ${ }^{1}$ Clean Clothes Campaign (CCC) finds that social audits were incapable of finding, reporting, or remedying violations of freedom of association (CCC 2005). In the aftermath of the CCC report, an empirical study conducted by Barrientos and Smith (2006) on the impact of the Ethical Trading Initiative (ETI) Base Code in South Africa, Vietnam, India and Costa Rica also observed limited impact in relation to freedom of association, discrimination, regular employment and harsh treatment, where serious issues frequently remained. Similar considerations transpire from Koçer and Fransen's (2009) study on the impact of codes in three Turkish apparel manufacturers. They observe that codes are unlikely to lead to remarkable improvements in freedom of association and collective bargaining, but they qualify that they might provide some protection when there is nothing else to rely on (Koçer and Fransen 2009: 254). Taken together, these recent empirical findings appear to confirm the existence of an enduring disjuncture between MNCs' commitments to trade union rights and decent work, as enshrined in codes of conduct, and the reality of trade unions' rights in the global South. 


\section{New Instruments of Social Compliance for the Advancement of Trade Union Rights}

The only existing instruments of global social compliance that position freedom of association and collective bargaining at the centre of relations between organised labour and MNCs are the proliferating International Framework Agreements. Setting the IFAs apart from codes of conduct are four characteristics identified by Hammer (2005: 218):

[IFAs]...establish a platform for international industrial relations in defining GUFs legitimate bargaining partners. They clearly move beyond codes of conduct in that they are not mere unilateral declarations, but contain obligations, although not legally enforceable ones. In addition, they deal with government failure by setting global minimum standards and by getting MNCs to accept some responsibility for the labour rights situation throughout the supply chain. Finally, labour is one of the main actors in the implementation as well as a regular monitoring process.

Although the ITGLWF has been a latecomer in the negotiation of an international framework agreement (Miller 2004, Miller 2008) it has consistently positioned trade union rights and industrial relations as a cornerstone in its understanding of the role of an IFA. Whereas in some quarters, IFAs may be conceptually understood as 'soft accountability mechanisms under the banner of corporate social responsibility', (Papadakis 2008: 2, Croucher and Cotton 2009: 61) most Global Unions understand their purpose as an enabling instrument for upholding fundamental rights at work and specifically and, perhaps most crucially of all, as a tool which can assist in organising workers into trade unions (Wills 2002). A common denominator across the whole spectrum of existing IFAs (i.e. 72 as of October 2008 ) is that all unanimously refer to the rights of trade unions to freely associate (ILO Convention n. 87) and bargain collectively (ILO Convention n. 98). Whilst these core conventions can be found in almost every corporate code of conduct, the unilateral mode of implementation of such instruments has meant that, until recently, trade unions have been generally excluded from the processes of social compliance much to the detriment of trade union rights in the apparel sector in particular. For a period, the ITGLWF was compelled to view codes of conduct as a 'necessary evil' and to use the trade union rights provisions in the same as levers in the resolution of urgent appeal cases, particularly those involving victimisation, retrenchments of union officials and the use of compensation sums to fend off the return of reinstated union officials. During the last 5 years, the ITGLWF has moved resolutely to develop relationships at a global level, in some cases via joint involvement in multi-stakeholder initiatives such as the MFA Forum and the Ethical Trading Initiative, and with some major retailers and brand-owners including NIKE, NEXT and GAP to involve its affiliates in these companies' compliance efforts (Miller 2004).

In 2005, following joint work on a relief scheme to support the victims of a factory collapse in Bangladesh, the ITGLWF and Inditex moved towards the signing of an IFA which was finally concluded in October 2007. Tangential to the pursuit of an IFA with a MNC the ITGLWF, primarily through the late Secretary General Neil Kearney, was actively promoting 
an approach to resolving labour disputes and advancing core labour standards in garment and apparel transnational supply chains. In a speech entitled 'Life beyond Codes' Kearney made the following comment:

Given the results to date we are convinced that the industrial relations route provides the key to sustainable labour standards compliance through supply chains. We see the traditional application of codes of conduct through auditing as being merely diagnostic with the enterprises involved requiring support to develop mature industrial relations systems and training for both management and workforce to make them function effectively. We believe that this will be a much more efficient use of resources than the current obsession with policing through inadequate social auditing. (ITGLWF, 2007c)

The development of the mature systems approach can be traced back to the resolution of a number of trade union rights violations amongst Inditex suppliers in Bangladeshi, Cambodian and Peruvian garment factories which took place between 2005 and 2008. It was articulated in a series of speeches and press releases by Kearney, and can be summarised as consisting of six core elements: a recognition of the need to rationalise the plethora of codes of conduct governing the sector; an acknowledgement of the weakness of social auditing; a prioritisation of the 'enabling rights' of freedom of association and collective bargaining; the establishment of the primacy of the employment relationship between a supplier and its employees; the redundancy of any role for an NGO in the workplace; and finally an appreciation of the relationship between productivity increases and the existence of sound workplace relations (Miller, Turner and Grinter 2008).

The resolution of the aforementioned disputes led to the introduction of management systems - agreements specifying trade union recognition, grievance, disciplinary and disputes procedures, and training - in an attempt to lay the basis for more sustainable local compliance and the eventual abandonment of auditing models. Resorting to and invoking 'mature systems of industrial relations' has now become such a recurrent feature in the relationship between the ITGLWF and Inditex that such an approach can be understood as the most evident concretisation of the only IFA in outsourced apparel supply chains (FNV Mondial 2008).

\section{The IFA at River Rich}

Whilst IFAs have begun to attract a great deal of attention (Stevis and Boswell 2007, Papadakis 2008), with few exceptions, ${ }^{2}$ little is known about their implementation mechanisms and outcomes, or the ways in which company signatories respect ethical commitments to freedom of association and collective bargaining in the global South. The ITGLWF's approach to the implementation of its IFA requires absolute employer support of the principles of freedom of association and collective bargaining which, arguably, can only come from some form of 'higher' commitment cemented in a formal agreement. In this paper we utilise a case study approach to gain a richer understanding of what the IFA means in practice, particularly in the context of Cambodia. More specifically, the case of River Rich 
illustrates how a recognition dispute was ultimately resolved with the introduction of systems of industrial relations. The case and the analysis are informed by semi-structured interviews with Cambodian trade unionists and union activists, ILO officers, arbitral awards, official press releases, NGOs campaign material and e-mail correspondence with the ITGLWF, Inditex SA, H\&M and River Rich. By tracing the history of the labour disputes at the Cambodian knitwear factory River Rich and appraising their resolution through two successive industrial relations agreements, in the remainder of this paper we unravel the constitutive elements, scope and effects of this enhanced approach to social compliance.

\section{SOCIAL COMPLIANCE AT RIVER RICH}

Located in Khandal province, and established in 2005, River Rich is a garment factory primarily engaged in the production, linking and finishing of knitwear, caps, scarves, socks and gloves for the European market. ${ }^{3}$ The factory was purchased by its main trading partner in July 2006 for the sum of US\$ 6.9 million, and is now one of the six wholly owned production facilities of the Hong Kong based Group Addchance Holdings Limited. Addchance's acquisition of River Rich was primarily motivated by a desire to reduce dependency on subcontractors, the need to enhance the capacity to cater for increased demand of finished knitted goods and the strategic requirement of reducing the risks arising from EU and US quota restrictions placed on knitted goods originating from its four Chinese operations (Addchance 2006b). Shortly after purchasing River Rich, Addchance proposed and finalised the acquisition of another Cambodian knitwear factory, and in October 2006 it became the proprietor of Winner Knitting Factory.

The ownership of River Rich reflects the historical pattern of foreign direct investment (FDI) within the Cambodian garment industry which accelerated from the mid-1990s. At the time, with a more stable economy and incentives offered for greenfield investment and acquisitions of state owned enterprises, Asian investors from Hong-Kong, Taiwan, Malaysia and Singapore began to open factories producing textile and garments (Arnold 2006: 7). Even with the imposition of export quotas as part of the Trade Agreement on Textile and Apparel (TATA) signed in January 1999, the growth and investment in the industry continued apace. By 2005, the ILO estimated that over 200 garment factories were present in Cambodia, accounting for $12 \%$ of the country's GDP and $80 \%$ of its exported goods (Better Factories Cambodia 2005). When these statistics were compiled, only $10 \%$ of the factories were in Cambodian ownership. As indicated by Frost and Ho (2006: 41): 'Hong Kong and Taiwan account for the ownership of nearly half of the factories in the sector.' The pattern of ownership is also mirrored in the membership composition of the largest employers group in Cambodia, the Garment Manufacturing Association of Cambodia (GMAC), which is dominated by manufacturers from Hong Kong and Taiwan (i.e. 51.02\%) and of which River Rich is a member. ${ }^{4}$

Formally registered as an export processing garment enterprise, River Rich is subject to social compliance inspections under the ILO Better Factories Cambodia (BFC). ${ }^{5}$ The ILO labour monitoring programme - a programme unique to Cambodia - originated from the TATA which made provisions on export quota allocation dependent upon compliance with Cambodian labour law (10 January 1997) and ILO core labour standards. Prior to the expiry of the Multi Fibre Agreement (MFA) social compliance through the BFC monitoring and 
reporting mechanisms was voluntary, however it was also 'encouraged' by a Prakas (implementing decree) issued by the Ministry of Commerce which linked access to the US market to BFC inspections (FIAS 2005: 3). When the MFA ended in January 2005, the ministerial decree became redundant and participation in the ILO programme became a condition for the concession of an export license (Better Factories Cambodia, nd).

Given its relatively young age, the River Rich factory appears only in two out the twenty-one bi-annual synthesis reports published by the BFC, namely Report $\mathrm{n} .17$ released in October 2006 and Report n. 19 published exactly a year later. From 2001 up to March 2006 (Report n. 16), the publicly available BFC synthesis reports provided an aggregate summary of the audit findings against core labour standards and gave details on the uptake of the recommendations made to each factory. River Rich however joined the ILO programme when the BFC introduced new computerised auditing systems (i.e. Information Management Systems) and new reporting policies. In accordance with the new reporting procedures, the reports issued after March 2006 only provide aggregate auditing scores; this means that the names of labour rights violators (and persistent violators) are no longer accessible. Such change effectively makes the new BFC significantly less transparent. A more substantial critique was articulated by C.CAWDU (Coalition of Cambodian Apparel Worker's Democratic Union) President who suggested with the introduction of the new reporting mechanisms all the employers partaking in the ILO monitoring exercise, even those that discriminate against unions, come across as 'good'. ${ }^{6}$ Monitoring alone, from the perspective of a local trade union, does neither fully ensure the respect of freedom of association, as sanctioned in Cambodia's labour law, nor does it promote social dialogue. ${ }^{7}$

Full access to the 500 items checked by the BFC factory advisers and a detailed synthesis of the audits' findings and a summary of audits and the findings is only available to the members of the $\mathrm{BFC}^{8}$ (i.e. the 280 Cambodian garment factories partaking in the programme and the 32 international buyers who subscribe to the IMS). River Rich main buyers, H\&M and Inditex, joined the BFC respectively in 2005 and 2008. The BFC is expected to avoid audit duplication, reduce the cost of monitoring and enhance the quality and effectiveness of social compliance; both companies nonetheless continue to rely on their own auditing systems. H\&M, for example, keeps its own auditing mechanisms to ensure compliance with the H\&M Code of Conduct and its environmental provisions': 'The controls carried out by BFC do not replace H\&M's own monitoring, but BFC's assessments do provide verification of the results of our audits. Moreover, the information provided by the BFC facilitates H\&M's initial selection when looking to co-operate with new producers in Cambodia' (H\&M 2006: 8). Likewise, the Inditex 2007 Financial Report indicates that Tested to Wear social audits have been carried amongst its Cambodian suppliers' base and more audits were planned for 2008 (Inditex 2007: 77-78).

\section{RIVER RICH WORKERS: ORGANISING, DISMISSALS AND DISPUTES}

Despite the existence of these overlapping systems of compliance, a number of labour disputes and strikes broke out at River Rich immediately after the formation of an independent union at the factory. At the time, according to figures collected by the ATNC (Asian Transnational Corporation Monitoring Network), the River Rich workforce comprised 1,748 workers, and as is the case with the majority of the labour force within the Cambodian 
garment sector over $90 \%$ of River Rich workers were women (Cfr: Better Factories Cambodia 2006). Furthermore, 70 to $80 \%$ of the workforce was employed on fixed duration contracts (FDCs) despite having worked for the factory for a period ranging from 6 months to 2 years (ATNC 2007). Whilst FDCs are permissible under the Cambodian labour law, and are the contract type of choice for garment factories' employers; their usage has dramatically increased since the conclusion of the MFA (Arnold, 2008). In interviews conducted by the Clean Clothes Campaign with Athit Kong, Vice President of C.CAWDU, and Phereak Ly of the women's rights NGO, Womyn's Agenda for Change (WAC) the two Cambodian labour activists identified a number of problems with the use of flexible contracts, namely a trade-off between freedom of association and flexible contractual agreements, and the leverage FDCs concede to employers:

Athit Kong: '...Before, workers would be on permanent contracts but now lots are employed on one to three month contracts, even if they have worked at the same factory for over two years. If workers are on temporary contracts, it's really hard to form a union. They will be immediately fired or just not get their contracts renewed.' (CCC 2007)

Phereak Ly: '...It also means workers are under a lot of pressure. If you refuse overtime or take sick leave, if you don't meet your targets all the time, or try to speak out about your problems, they say you are not a good worker and won't renew your contract.' (CCC 2007)

Workers at River Rich were eager to unionise primarily to put a halt to the overwhelming usage of FDCs, the denial of leave permits and miscalculations in wage payments. ${ }^{10}$ On 24 October 2006, a request to hold elections was sent by C.CAWDU to the management of River Rich. Despite threats of dismissal to labour activists in the ironing section the election took place on 29 October. The ATNC documents that 345 workers participated in the elections, 10 male workers and 5 female workers were competing for the union's leadership posts (i.e. President, Vice President and Secretary General), which were eventually won by 3 male candidates (ATNC 2007). ${ }^{11}$ Only three days after the election, River Rich dismissed 19 union members and leaders; shortly afterwards another 98 short-term workers, including another 11 union activists, were dismissed (See: Table 1) because their contracts had allegedly expired and production was low. In response to what was perceived as anti-union activity C.CAWDU sent a formal complaint to the Provincial Labour Inspector in Khandal. 
Table 1: Terminations at River Rich

\begin{tabular}{|l|c|}
\hline Date & No. Workers Dismissed \\
\hline 31 October 2006 & 19 \\
\hline 2 to 3 November 2006 & 97 \\
\hline 3 to 21 November 2006 & 1 \\
\hline Total & 117 \\
\hline
\end{tabular}

Source: Compiled by the authors from Cambodia Arbitration Council (2007).

An attempt to solve the dispute was facilitated by the Ministry of Labour and Vocational Training (MOLVT) but the collective labour dispute dated 24 November failed to resolve a number of issues tabled by C.CAWDU. In accordance with Cambodian labour law the outstanding issues were referred by the MOLVT to the Arbitration Council. An offshoot of the TATA and a brainchild of the ILO, the Council is the only tripartite tribunal in Cambodia that deals specifically with labour disputes and issues awards (Adler, Sage and Woolcock 2009). In dealing with the River Rich and C.CAWDU dispute, the Council hosted hearings in December and issued a non-binding award in January 2005. The award ruled in favour of River Rich and recommended against the re-instatement of the union leaders and members. In response, C.CAWDU demanded that workers employed for more than two months be given a contract of indeterminate duration (Cambodia Arbitration Council 2007).

\section{TRANSNATIONAL SOLIDARITY AND THE PRIVATE SETTLEMENT OF LABOUR DISPUTES}

Arnold (2006: 17) suggests that in Cambodia it is typical for workers to appeal directly to international buyers when they experience problems in their factory"; the President of C.CAWDU clarified that when workers are unionised and all the local remedies have been unsuccessfully exhausted, unions call for solidarity actions. In attempting to resolve the dispute at River Rich, C.CAWDU appealed to cross-border solidarity as it did earlier on in the year to draw attention to ongoing union discrimination at Goldfame Enterprises International Knitters. The ITGLWF was hence alerted of the situation and, in January 2007, made contacts with River Rich main buyers (ITGLWF 2007a). Both H\&M and Inditex were made aware of the union's demands, which included the reinstatement of thirty dismissed union members, permanent employment status for workers with more than two months seniority, the provision of written and comprehensible employment contracts and the payment of maternity allowance for the whole period of confinement. Failure to investigate the disputes and consider the workers' demands would have ushered allegations of breaches of the companies' respective codes of conduct and potentially damage the reputation of the Zara and H\&M brands. However, the types of interventions adopted by the buyers differed significantly. H\&M agreed with the jurisdiction of the Council and preferred not to get involved (ITGLWF 2007a). Inditex, on the other hand, was persuaded by the ITGLWF General Secretary to bypass the Arbitral award and hold talks with C.CAWDU and the management of River Rich. 
On 3 February 2007, the ITGLWF and representatives of Inditex met with the supplier, the union and the Cambodian arbitrators. The meetings resulted in a formal agreement which contained a series of short-term and long-term commitments. River Rich agreed to immediately re-instate the 30 trade unionists as of March 2007, and to drop all legal charges mounted against them. They furthermore undertook to re-train the 30 workers, and upon reinstatement, begin dialogue, consultation and negotiation with C.CAWDU in accordance with industrial relations practice. The agreement reached by the parties provided for trade union recognition and the development of dialogue, consultation and training on industrial relations. In the long-term, the ITGLWF promised to offer the union assistance in mentoring and training activities with the view on establishing a joint trade unions council in the factory, whilst Inditex, as a principal buyer, pledged to undertake periodic reviews and finance training activities for the management and workers. Moreover, River Rich in conjunction with Inditex committed to undertake an analysis of the use of workers on shortterm contracts with a view to eliminate such practice (ITGLWF 2007b).

The fourth clause in the agreement's addendum deserves some attention because it introduces the scope of the intervention and specifies its constitutive elements. These included: trade union recognition; daily briefings on production and other problems and objectives; fortnightly meetings on general industrial relations matters including working conditions, productivity and training; a procedure for handling grievances and complaints and a procedure for the handling of disciplinary action. With these elements in place, the spirit of the agreement was to render River Rich 'a viable, profitable and internationally competitive enterprise based on good working practices in accordance with Cambodian labour law and international labour standards'.

River Rich did not uphold the February commitments and, throughout May, four strikes were organised outside the factory gates demanding the immediate reinstatement of the workers. The last strike, staged on May 21, 2007, was by far the largest and most violent: it involved approximately 1000 workers and was met by 150 riot police equipped with tear gas, guns, electric batons and shields (LIDACHO 2007). The commotion of the event prompted an alliance of Hong-Kong based NGOs, international NGOs (i.e. Clean Clothes Campaign), and local and international unions to join forces in an effort to put an end to the trade unions' rights violations at River Rich. The ATNC Monitoring Network - an alliance comprising 20 labour and human rights organisations and trade unions in 12 Asian countries, including 2 labour organisations in Cambodia - co-ordinated the campaign in close co-operation with C.CAWDU. The ATNC website was employed as a vehicle to monitor and later condemn the violations.

The urgency of the appeal and the direct allegations made by the ATNC against the ZARA brand and H\&M required a second intervention. In early June, the ITGLWF went back to Cambodia and arranged a meeting with the management of the Addchance group, the management of River Rich, Inditex SA, a representative of H\&M, C.CAWDU and GMAC. During the 3-day long meeting the February agreement was re-affirmed ${ }^{12}$ and a number of additional provisions were stipulated, namely the immediate permanent reinstatement of the 30 workers with payments of average earnings since the day of dismissal, the cessation of legal action against the dismissed workers, the gradual phasing out of short-duration contracts across the whole workforce, and promotion of 'good industrial relations' through training and dialogue (ITGLWF 2007b). 


\section{The IFA at River Rich: A Victory for Workers Rights?}

Taking stock of the outcomes following signature of the second agreement between CCAWDU and River Rich management, what gains have been made for the workers at the factory? In the immediate aftermath of the agreement there were some recognisable developments and victories for the workers and union members at River Rich. Indeed, parts of the agreement have been respected and out of the 30 union members that were offered reinstatement, 25 accepted the offer, whilst the other 5 found employment elsewhere. In line with the stipulations, all the workers who returned to work at River Rich received back payments in the region of US\$ 1,100 (ITUC 2007b: 7). Significantly, all the 2500 workers at the plant (See: Table 2) have been given indeterminate contracts, making River Rich one of the few garment factories in Cambodia where short-term contracts have been eliminated. ${ }^{13}$ Furthermore, shortly after this victory, the ITGLWF planned to negotiate an equivalent agreement with River Rich sister company (ITUC 2007b: 7).

The agreement has also been decisive in enabling the recognition of the right to unionise and the initiation of dialogue between the union and management (ITUC 2007b: 7). As illustrated in a remark made by Neil Kearney at the World Retail Congress:

In the River Rich enterprise not a single day's work has been lost in the two years since these systems were adopted. There, trade unions consult and recommend how work be allocated between lines, a continual source of dispute in the past. Mature industrial relations don't eliminate problems but it provides a mechanism where these can be anticipated, identified and dealt with before they escalate into disputes. (ITGLWF 2009)

This was amplified in interviews with trade unionists at River Rich who confirmed that dialogue now took place between trade union and management. However, on two separate occasions the parties resorted to the Arbitration Council for disputes regarding maternity payments, health checks and redundancies, confirming that potential conflicts of interest still remained but that the parties were resorting to institutional mechanisms rather than engaging in industrial action.

Since June 2007, the membership of C.CAWDU increased by fivefold thus allowing the union to numerically gain most representative status at the plant (See: Table 2). The union also learned how to call upon national and transnational support and to organise industrial actions. Furthermore, C.CAWDU earned a favourable reputation amongst garment workers in Khandal. As the President of C.CAWDU recalls: '...it was a very organised campaign which involved local union leaders, industrial action, media and the intervention of Inditex. It was important to win at River Rich, C.CAWDU became known in other factories as well. ${ }^{14}$ An additional outcome of the process was that CAWDU and C.CAWDU acquired negotiating skills all valuable for future negotiation rounds with the management and the buyers. ${ }^{15}$ So far, however, attempts to initiate new bargaining rounds have been 'delayed' by management due to the uncertainties ensuing from the financial crisis. 
Table 2: River Rich Today

\begin{tabular}{|c|c|c|c|c|}
\hline Workers & Workers' Gender & Unions & C.CAWDU members & $\begin{array}{c}\text { C.CAWDU } \\
\text { gender }\end{array}$ \\
\hline 2500 & $\begin{array}{c}95 \% \text { of the } \\
\text { workforce is } \\
\text { female. }\end{array}$ & $\begin{array}{c}\text { C.CAWDU } \\
\text { CLUF } \\
\text { Khmer Youth }\end{array}$ & & $\begin{array}{c}90 \% \text { of union } \\
\text { members at River } \\
\text { Rich are women. }\end{array}$ \\
\hline
\end{tabular}

Source: Interviews with CAWDU leadership and activists at River Rich, Khandal, 24 March

2009.

Although positive direct and indirect effects ensued from the recognition disputes and their subsequent resolution, a number of substantive areas addressed in the IFA and by references to the ETI Base Code and the Inditex Code of Conduct remain unresolved, namely aspects of health and safety within the workplace and the payment of a 'living wage' and nonwage benefits. Union leaders and activists interviewed as part of this research were asked about the working conditions at the factory and they identified 'excessive heat' and 'dust' as being persistent health and safety problems which the management was made aware of but had not acted upon. They also indicated that wages, maternity leave payments and health check expenses were issues of concern. All the union activists unanimously agreed that the minimum wage rate should be increased to US\$ 82 per month from the national minimum rate of US\$ 50 as of March $2009 .{ }^{16}$ The average pay of US\$ 72 (inclusive of overtime, housing allowance and seniority bonus) was below what the workers perceived as an adequate 'living wage' to satisfy their needs and those of their dependants and families. Even though we were unable to determine whether the piece rate had been lowered or the workload increased, average wages have remained the same since the second agreement was concluded in 2007 (See: Marston 2007: 5). The demand for a minimum wage increase is obviously an issue which a relationship between a multinational and a global union as articulated via an IFA cannot hope to address single-handedly. Nevertheless, the IFA does expressly lay down the following:

External manufacturers, suppliers and their subcontractors shall ensure that wages paid for a standard working week shall meet, at a minimum, at least the legal or industry benchmark standards, whichever is higher. In any event, wages should always be enough to meet the basic needs of workers and their families and to provide some discretionary income. ${ }^{17}$

The ability of the union to bargain at plant level for higher piece rates and other wage elements is, however, circumscribed by the employer's ability to pay, which, in turn, is a function of the buying practices operating within the commercial department at Inditex and other multinational retailers sourcing from River Rich. We will return to this point in our concluding remarks. 
Some interviewees asserted that the agreements signed at River Rich are 'far too complex for Cambodia. ${ }^{18}$ According to ILO officials, unions might be compelled to sign an agreement which seeks to resolve immediate concerns (e.g. unfair dismissal and reinstatement) but might not have the capacity to use it effectively after the immediate resolution of industrial disputes. This is a particularly important point which reinforces, as stipulated in the agreement, the need to provide unions and management with training in industrial relations and social compliance. However, three years after the agreement was signed, training has not been provided and questions are being raised as to who should conduct it and finance it. ${ }^{19}$ In Cambodia, both the trade union movement and management are still relatively inexperienced as far as day-to-day dispute resolution is concerned, a factor which could not insignificantly be accelerated by training input.

The current financial crisis has, moreover, brought into sharp focus the fickle nature of apparel sourcing and the limited authority CSR departments have in commercial decision making. At the time of our interviews the global crisis had impacted upon order placements, threatening employment security and the victories secured since the stipulation of the agreements. Reflecting the deep impact of the crisis in the Cambodian apparel sector ${ }^{20}$ orders from Inditex at River Rich had slumped, a situation mirrored at a plant in Peru where a similar intervention by Inditex and the ITGLWF had resulted in the establishment of an industrial relations framework (Miller, forthcoming). Clearly, sourcing policy and purchasing practices $^{21}$ are variables over which the IFA approach, at present, has very little say. The impact of buying practices on staffing decisions are difficult to isolate during a period of economic downturn, however we were informed by the River Rich trade union committee that a number of workers with indeterminate contracts had been laid off ${ }^{22}$ and replaced by agency workers at times of sudden peaks in orders. At the time of our interviews it was reported that 50 casual workers had been offered intermittent work across various departments at River Rich. ${ }^{23}$ In such circumstances, putting a halt to flexibilisation and casualisation through trade union pressure becomes problematic. The extent to which the crisis had led to a form of concession bargaining was unclear but union leaders admitted to having avoided confrontation with management out of fear that production would be shifted to a River Rich sister plant (i.e. Winner Knitting Factory), with more jobs lost as a result. ${ }^{24}$

The sustainability of strong industrial relations is heavily dependent on the existing commercial relationship flourishing between the supplier in question and the signatory of the IFA, and that such a relationship is one where the buyer has a significant percentage of the production at the supplier's facility. In a volatile sourcing environment such as apparel, the IFA can become a transient mode of compliance since there is no guarantee that Inditex will continue sourcing from River Rich, and consequently that River Rich would comply with the conditions negotiated with Inditex and C.CAWDU. From the perspective of the trade unions, should C.CAWDU lose its most representative status within the plant - a $51 \%$ union membership - the agreement does not stipulate whether the same 'entitlements' and conditions would be re-negotiated with or extended to a different union or a union not affiliated to either C.CAWDU or the ITGLWF. Such observations would appear to suggest that an IFA, along with other voluntary forms of supply chain governance, may only have purchase under conditions of a long-term strategic supply agreement between a buyer and a supplier. Because of the fickle and segmented nature of the global fashion market, such supply agreements are likely in what might be termed the 'basics' market niche. At present, supply 
agreements between multinationals and their commercial partners are however some way off the agenda for action of the ITGLWF.

\section{Conclusions}

In this paper we have attempted to further the debate on alternative approaches to global social compliance by critically assessing the application of the only IFA in the apparel sector. By charting the labour dispute at River Rich the paper has sought to determine what the IFA means in practice, the point at which it was engaged and by whom, and the outcomes it produced in this instance. We found that the introduction of industrial relations agreements at River Rich were not effected as a proactive measure, anticipated by any existing instrument of social compliance, but followed a series of labour disputes, industrial action and international campaigns that caused significant disruptions to production and threatened to tarnish the reputation of two global brands. Although a system for managing industrial relations was negotiated in the first instance, the supplier did not abide by the agreement and a local union had to make a repeated call for international solidarity action and enlist the assistance of a global union and a coalition of labour rights organisations to remedy a recognition dispute.

The most visible impacts of the intervention by Inditex and the ITGLWF were undoubtedly a final recognition of C.CAWDU and the elimination of FDCs. However, despite a provision in the agreement, to date there has been no training provision for the union representatives at River Rich. Furthermore, the absence of orders from Inditex to River Rich during much of 2010, a situation mirrored elsewhere in the multinational's supply chain, not only highlights the fragile nature of the achievements at this factory, but throws into question one of pillars of the mature systems of industrial relations approach pursued by the ITGLWF, namely the primacy of the employment relationship. In the globalised world of outsourced apparel production, to what extent can an employment relationship based on collective agreements withstand the commercial forces at work in an apparel supply chain where the terms of trade are heavily dictated by the buyers? Inditex and H\&M both operate in a highly competitive retail environment which not only has major implications for the organisation of production but also undoubted potential impacts on the sustainability of industrial relations established by absentee third parties in supplier factories.

In many respects, in shifting from the national to the global, nothing has changed in the trade union approach to industrial relations, with priority focusing in the first instance on procedural matters in order to address ongoing substantive issues. For the ITGLWF, this is the central plank of its mature systems of industrial relations approach: it draws attention to the violation of fundamental worker rights as laid down in codes of conduct as a lever to achieving trade union recognition to then introduce management systems in supplier factories. In this respect, a global union seeking to implement an IFA is no different from a global union seeking to enforce a multinational's code of conduct, although the nature of the relationship and understanding between the officers of a global union and their CSR counterparts may differ in these two scenarios. The River Rich case highlights, above all else, the need to extend the 'frontier of control' into the area of buying practices in order to protect workers from the substantive insecurities arising from sourcing decisions made by other quarters in a 
multinational. In many respects this is as much a battle which corporate social responsibility managers as well as trade unionists need to wage. We would argue that long-term supply agreements between multinationals and their external suppliers need to be on the framework agreement bargaining agenda of global unions in such manufacturing environments. In the volatile world of 'fast' fashion this will be a tough but necessary call.

Furthermore, as the ITGLWF seeks further IFAs with other MNCs and develops relationships between global retailers, brand-owners and ITGLWF affiliates, Bronfenbrenner (2007: 218) is right to remind us that the authority of an IFA '...is only as good as the power of the multilevel grassroots networks of workers and their allies in labour organizations and NGOs to enforce those agreements, through local, national and international action'. This perspective would necessitate a greater focus in disseminating the provisions of the IFA amongst affiliates and workers' networks in the global South. At a time when union resources are scarce and international donors scale back, the task of dissemination will be a challenging one, but one which hopefully the planned new manufacturing global union between the International Metalworkers Federation, the International Federation of Chemical, Energy Mine and General Workers Unions and the ITGLWF can meet.

\section{ACKNOWLEDGEMENTS}

An earlier version of this paper was presented at conference 'Regulating For Decent Work: Innovative Labour Regulation in a Turbulent World', ILO, Geneva, 8-10 July 2009. We would like to thank the conference participants, Veasna Noun for facilitating the fieldwork in Cambodia, and the two anonymous referees for their helpful comments.

\section{NOTES}

'These are the Clean Clothes Campaign, the Ethical Trading Initiative, the Fair Labour Association, the Fair Wear Foundation, Social Accountability International and the Workers' Rights Consortium.

${ }^{2}$ To the authors' knowledge the only academic studies that provide an evaluation of two IFAs are Jane Wills (2002) and Lone Riisgard (2005).

${ }^{3}$ Sales made to H\&M and Inditex accounted for approximately $\mathrm{HK} \$ 384.8$ million, which represented approximately $85.4 \%$ of the Group's sales of knitted sweaters for the year 2006 (Addchance 2006a).

${ }^{4}$ Once a factory is formally registered it also must become a member of GMAC.

${ }^{5}$ Kevin Kolbent (2004) and Miller et. al. (2009) provide an excellent historical overview of the BFC. 
'Interview with C.CAWDU President, Phnom Penh, 24 March 2009.

${ }^{7}$ Interview with Ath Thorn, C.CAWDU President, Phnom Penh, 24 March 2009. It is important to add that some trade union activists recognised the value of training in negotiation, collective bargaining, most representative status and CSR imparted by the BFC and two complementary ILO initiatives operating in Cambodia - the ILO Dispute Resolution Project (Phase III) and the ILO Workers' Education Project.

${ }^{8}$ Interview with BFC Chief Technical Advisor, Phnom Penh, 23 March 2009.

${ }^{9}$ Email correspondence with H\&M Head of CSR, 26 November 2009.

${ }^{10}$ Email correspondence with Ath Thorn, C.CAWDU President, 10 January 2010.

${ }^{11}$ The gender bias in trade union leadership is not isolated to this single case, as recalled by a Senior Programme Office at ACILS, only $15 \%$ of trade union local leaders in the Cambodian garment sector are women while female membership accounts to a staggering $90 \%$. Interview with Senior Programme Officer American Center for International Labour Solidarity (ACILS) Cambodia, Phnom Penh, 26 April 2009.

${ }^{12}$ Whilst the first agreement had no legal validity the second agreement was registered with MOLVT to allow further disputes to be resolved through Cambodian conciliation and arbitration mechanisms (ITGLWF 2007a).

${ }^{13}$ Interview with An Nan, Arbitrator Cambodian Arbitrator Council and Workers Rights Consortium, Phnom Penh, 23 March 2009.

${ }^{14}$ Interview with Ath Thorn, C.CAWDU President, Phnom Penh, 24 March 2009.

${ }^{15}$ Interview with John Richotte, Chief Technical Advisor ILO Dispute Resolution Project, Phnom Penh, 23 March 2009.

${ }^{16}$ This was negotiates nationally in 2006, see: Miller and Williams (2009: 107).

${ }^{17}$ Annex 1 to the International framework agreement between Industria de Diseño Textil, SA and the International Textile, Garment and Leather Workers Federation on the implementation of international labour standards throughout the Inditex supply chain.

${ }^{18}$ Interview with John Richotte, Chief Technical Advisor ILO Dispute Resolution Project, Phnom Penh, 23 March 2009. And, Interview with Tuomo Poutiainen, Chief Technical Advisor ILO Better Factories Cambodia, Phnom Penh, 23 March 2009.

${ }^{19}$ Interview with Senior Programme Officer ACILS Cambodia, Phnom Penh, 26 April 2009; and email correspondence with Ath Thorn, C.CAWDU President, 10 January 2010. 
${ }^{20}$ Across the whole Cambodian garment industry there has been a 45\% drop in production since the financial crisis began. Interview with Mr. Som Chamnan, Executive Manager CAMFEBA, Phnom Penh, 27 March 2009.

${ }^{21}$ Inditex is a company which has pioneered the 'fast fashion' retail model which calls for reduced lead times and constant modifications to product design. This is an approach which can have a short-term impact on production and factory management and is an area which needs further empirical research.

${ }^{22}$ Interview with Ath Thorn, C.CAWDU President, Phnom Penh, 24 March 2009.

${ }^{23}$ Interviews with CAWDU activists and leadership at River Rich, Khandal, 24 March 2009.

${ }^{24}$ Interviews with CAWDU activists and leadership at River Rich, Khandal, 24 March 2009.

\section{REFERENCES}

Addchance (2006a) Annual Report 2006. Hong Kong: Addchance Holdings Limited. http://www.addchance.com.hk/download/annual/0000000011/2006_Annual_Report.pdf, (accessed 16 April 2009).

Addchance (2006b) 'Circular - Proposed Acquisition of River Rich Textiles Ltd.', August 2006.

http://www.addchance.com.hk/download/announcements/0000000018/2006_Jul_11_Acquis ition_of_the_entire_share_capital_of_River_Rich.pdf, (accessed 3 March 2009).

Adler, D., Sage, C. and Woolcock, M. (2009) 'Interim Institutions and the Development Process: Opening Spaces for Reform in Cambodia and Indonesia', University of Manchester, Brooks World Poverty Institute, Working Paper No. 86.

Arnold, D. (2006) 'The Cambodian Experiment in Ethical Production: Dynamics of a GMO Approach to Promoting Labour Rights and Investment', Paper presented at the workshop on 'Multinational Production and Labour Rights', University Center for International Studies, UNC Chapel Hill, 22-24 September 2006.

Arnold, D. (nd) 'Creating Precarity: Labour Law in Cambodia 1', Asia Monitor Resource Centre.

http://www.amrc.org.hk/alu_article/informalization_of_labour_in_asia/creating_precarity_lab our_law_in_cambodia1, (accessed 17 April 2009).

ATNC (2007) 'Fact Sheet of River Rich Textile Ltd. Factory', 21 May 2007. http://atnc.org/html/campaign/river-rich-garment/river-rich-textile-ltd.-factory, (accessed 3 March 2009). 
Barrientos, S. (2008) 'Contract Labour: The "Achilles Heel" of Corporate Codes in Commercial Value Chains', Development and Change 39(6): 977-990.

Barrientos, S. and Smith, S. (2006) The ETI Code of Labour Practice: Do Workers Really Benefit? Brighton: Institute of Development Studies, University of Sussex.

Better Factories Cambodia (nd) 'Why it Works'. http://www.betterfactories.org/ILO/aboutBFC.aspx?z=2\&c=1, (accessed 16 April 2009).

Better Factories Cambodia (2005) 'Facts and Figures'. http://www.betterfactories.org/content/documents/Facts\%20and\%20Figures.pdf, (accessed 20 April 2009).

Better Factories Cambodia (2006) 'Cambodia - Women and Work in the Garment Industry', Phnom Penh: Better Factories Cambodia. http://www.betterfactories.org/content/documents/1/Women\%20and\%20Work\%20in\%20t he\%20Garment\%20Industry\%20(en).pdf, (accessed 16 April 2009).

Bronfenbrenner, K. (2007) 'Conclusion', in K. Bronfenbrenner (ed) Global Unions Challenging Transnational Capital through Cross-Border Campaigns (pp. 213-225). ILR Press: Itacha and London.

Cambodia Arbitration Council (2007) 'Arbitral Award 112/06-River Rich', 5 January 2007. http://www.arbitrationcouncil.org/pdf_files/awards/112-06-River\%20Rich.pdf, (accessed 10 April 2009).

Clean Clothes Campaign (2005) 'Freedom of Association and the Right to Collective Bargaining - A Clean Clothes Campaign Premier Focussing on the Global Apparel Industry', September 2005. http://www.cleanclothes.org/codes/docs/CCC_FoA_Primer.pdf, (accessed 10 May 2009).

Clean Clothes Campaign (2007) 'We Are Not Machines; But They Want Us To Be', Newsletter No. 24, October 2007. http://olympicflame.org/about-us/416, (accessed 17 April 2009).

Croucher, R. and Cotton E. (2009) Global Unions Global Business - Global Union federations and International Business. London: Middlesex University Press.

FIAS (2005) 'AIDE MEMOIRE - Labor Standards Monitoring, Reporting and Remediation in the Cambodian Garment Sector: Current Status, Desired End State, and Recommendations,' $12 \quad$ January 2005. http://www.ifc.org/ifcext/economics.nsf/AttachmentsByTitle/Cambodia+FIAS+Aide+Memoir e/\$FILE/Cambodia+FIAS+Aide+Memoire.pdf, (accessed 16 April 2009). 
FNV Mondial (2008) 'An Introduction to International Framework Agreements', February 2008. http://www.fnv.nl/binary/International\%20Framework\%20Agreements_tcm718663.pdf, (accessed 1 May 2009).

Frost, S. and Ho, M. (2006) 'The End of the MFA and Apparel Exports: Has Good CSR Allowed Cambodia to Hold Steady Against China in a Quota Free Environment', Corporate Social Responsibility and Environmental Management 13(1): 37-46.

H\&M (2006) CSR Reporting 2006. Stockholm: H\&M.

Hammer, N. (2005) 'International Framework Agreements: Global Industrial Relations Between Rights and Bargaining', Transfer 11(4): 51-530.

Inditex (2007) Annual Report 2007. A Coruña: Inditex Group.

ITGLWF (2007a) 'Solidarity Action Presidium Report 2007', Unpublished Manuscript, March 2007.

ITGLWF (2007b) 'Agreement Between River Rich Textile Limited and C.CAWDU Together with ITGLWF and Inditex, S.A.', 7 June 2007. http://www.itglwf.org/DisplayDocument.aspx?idarticle=15317\&langue=2, (accessed 21 April 2009).

ITGLWF (2007c) 'Time to Move to Life after Corporate Codes of Conduct', 7 December 2007. http://www.itglwf.org/DisplayDocument.aspx?idarticle=15453\&langue=2, (accessed 19 May 2009).

ITGLWF (2009) 'From Decent Work comes the Four Wins', Speech by Neil Kearney delivered at the World Retail Congress 2009, Barcelona, 7 May 2009. http://www.itglwf.org/DisplayDocument.aspx?idarticle=15739\&langue=2, (accessed 11 May 2009).

ITUC (2007a) 'Spotlight Interview with Ath Thorn', Brussels, 27 September 2007. http://www.ituc-csi.org/spip.php?article1435, (accessed 8 May 2009).

ITUC (2007b) '25 Trade Unionists Get Their Jobs Back Thanks to International Solidarity', ITUC Union View No. 5, September 2007. http://www.ituccsi.org/IMG/pdf/CambodgeEN.pdf, (accessed 29 April 2009).

Jenkins, R., Pearson, R. and Seyfang G. (2002) Corporate Social Responsibility and Labour Rights - Codes of Conduct in the Global Economy. London: Earthscan.

Koçer, R. G. and Fransen, L. (2009) 'Codes of Conduct and the Promise of a Change of Climate in Worker Organization', European Journal of Industrial Relations 15(3): 237-256. 
Kolbent, K. (2004) 'Trade, Monitoring, and the ILO: Working to Improve Conditions in Cambodia's Garment Factories', Yale Human Rights and Development Law Journal 7: 79-107.

LIDACHO (2007) 'Riot Police Clash with Cambodian River Rich Garment Factory Workers on Strike in Phnom Penh', 22 May 2007. http://www.licadhocambodia.org/articles/20070522/54/index.html, (accessed 22 April 2009).

Locke, R., Qin, F. and Brause, A. (2006) 'Does Monitoring Improve Labour Standards? Lessons for Nike’, Corporate Social Responsibility Initiative, Working Paper No. 24, John F. Kennedy School of Government, Harvard University.

Lipschutz, R.D. (2005) 'Doing Well by Doing it? Social Regulation and the Transnational Apparel Industry,' in R.D. Lipschutz with J.K. Rowe (eds) Globalization, Governmentality and Global Politics - Regulation for the Rest of us? (pp. 67-105). London: Routledge.

Martson, A. (2007) 'Labour Monitoring in Cambodia's Garment Industry: Lessons for Africa', The Ethical Globalization Initiative Special Report, 1 May 2007. http://www.realizingrights.org/pdf/Labor_Monitoring_in_the_Garment_Industry_May2007_ A_Marston.pdf, (accessed 29 April 2009).

Miller, D. (2004) 'Preparing for the Long Haul - Negotiating International Framework Agreements in the Global Textile, Garment and Footwear Sector', Global Social Policy 4(2): 215-239.

Miller, D. (2008) 'The ITGLWF's Policy on Crossborder Dialogue in the Textiles, Clothing and Footwear Sector: Emerging Strategies in a Sector Ruled by Codes of Conduct and Resistant Companies', in K. Papadakis (ed), Cross-Border Social Dialogues and Agreements - An Emerging Global Industrial Relations Framework? (pp. 159-189). Geneva: ILO Publications.

Miller, D., Turner. S. and Grinter, T. (2008) 'Back to the Future: Mature Systems of Industrial Relations Approaches and Social Compliance in Outsourced Apparel Supply Chains', Paper prepared for the conference Capturing the Gains, University of Manchester, December 2008.

Miller, D. and Williams, P. (2009) 'What Price a Living Wage?', Global Social Policy 9(1): 99-125.

Miller, D., Nuon, V., Aprill, C. and Certeza, R. (2009) 'Business as Usual? Governing the Supply Chain in Clothing Post MFA Phase Out: The Case of Cambodia', International Journal of Labour Research 1(1): 9-34.

Miller, D. (forthcoming) 'Global Social Relations and the Limits and Possibilities of Transformative CSR in Outsourced Apparel Supply Chains: The Case of the Inditex IFA,' in K. Papadakis (ed), Processes and Outcomes of an Emerging Global Industrial Relations Framework. London: ILR and Palgrave. 
O’Brien, R. (2002) 'The Varied Paths to Minimum Global Labour Standards,' in J. Harrod and R. O'Brien (eds), Global Unions? Theory and Strategies of Organised Labour in the Global Political Economy. (pp. 221-234). London: Routledge.

O'Rourke, D. (2003) 'Outsourcing Regulation: Analyzing Nongovernmental Systems of Labor Standards and Monitoring', The Policy Studies Journal 31(1): 1-29.

Oka, C. (2010) 'Accounting for the Gaps in Labour Standard Compliance: The Role of Reputation-Conscious Buyers in the Cambodian Garment Industry', European Journal of Development Research 22(1): 59-78.

Papadakis, K. (2008) 'Introduction', in K. Papadakis (ed), Cross-Border Social Dialogue and Agreements: An Emerging Industrial Relations Framework? (pp. 1-11). Geneva: ILO Publications.

Pruett, D. (2005) 'Looking For a Quick Fix: How Weak Social Auditing is Keeping Workers in Sweatshops,' Clean Clothes Campaign, November 2005. www.genombrott.se/maj/load_file.php?id=18, (accessed 25 May 2009).

Riisgard, L. (2005) 'International Framework Agreements: A New Model for Securing Workers Rights?', Industrial Relations 44(4): 707-737.

Stevis, D. and Boswell, T. (2007) 'International Framework Agreements: Opportunities and Challanges for Global Unionism,' in Bronfenbrenner, K. (ed) Global Unions - Challenging Transnational Capital through Cross-Border Campaigns (pp. 174-194). ILR Press: Itacha and London.

Wells, D. (2007) 'Too Weak for the Job: Corporate Codes of Conduct, Non-Governmental Organizations and the Regulation of International Labour Standards', Global Social Policy 7 (1): 51-73.

Wills, J. (2002) 'Bargaining For the Space to Organize in the Global Economy: A Review of the Accor-IUF Trade Union Rights Agreement', Review of International Political Economy 9(4): 675-700.

\section{BIOGRAPHICAL NOTE}

CATIA GREGORATTI is a Postdoctoral Fellow at Lund University. She has conducted her doctoral work in International Political Economy at the University of Manchester. Her research focuses on the influence of multinational corporations in global governance, transnational partnerships, and private regulation. 
DOUG MILLER was seconded from the University of Northumbria to the ITGLWF as research director where he was responsible for assisting the Global Union with multinationals policy development and implementation between 2000 and 2008. Since 2008, he has been driving a teaching and research strategy within the Design School at the University of Northumbria. His major research interests are the global governance of apparel supply chains, social labelling and sustainable labour costing in clothing production. He has just completed a book on the Spectrum Sweater Factory disaster in Bangladesh. 